\title{
Changes in the Strength Characteristics of Glinistx Soils under the Influence of Dynamic Forces
}

\author{
Khakimov Gayrat Akramovich
}

\begin{abstract}
In order to study in depth the impact of vibration on the strength characteristics of clay soils, as well as to develop methods that increase the strength characteristics and contribute to the elimination of seismic shrinkage deformations of clay soils, we conducted research in the field. In field experimental studies, the svaw-12 trailed, smooth vibration roller, manufactured in Germany, was used. We paid special attention to the further behavior of the soil after the vibration and made observations and measurements of soil indicators for two months. The experiments in the field with vibration column showed an increase of soil deformation with increasing duration of the fluctuations, i.e. there is a linear relationship between the increases in soil density on the duration of oscillations. In the process of vibration, there is a sharp decrease in the force of adhesion and the angle of internal friction, which is apparently associated with a violation of the structure of the soil and its compaction. And then at the end of the vibration process, over time, there is an increase in the adhesion (1.5-2 times) and the internal friction angle (1.2 times) of the soil, obviously as a result of the soil acquiring new strength and compaction under the influence of its own weight. This circumstance is also associated with the humidity state of the soil.

Keyword: strength characteristics of soils, mechanical properties of soils, resistance of soils to internal friction shift of soils, specific adhesion of soils.
\end{abstract}

\section{INTRODUCTION}

Strength is one of the main indicators that characterize one of the main indicators that characterize the mechanical properties of clay characterizing the mechanical properties of clay soils. Strength characteristics of soils used to solve important engineering task such as calculations of the stability of Foundation, bearing capacity determination his determination of the earth pressure on the building envelope, retaining walls, lining of tunnels, checking the stability of natural slopes and earth structures slopes, a limit of applicability of the theory of linearly-deformed bodies when calculating the residue of the Foundation, etc.The strength characteristics of soils, especially clay soils, are not constant, changing under the influence of many natural and artificial factors, such as the state of density-humidity, excessive pressure in pore water, loading speed, deformation value, temperature, loading mode, duration of normal and tangential stresses, as well as under the influence of various dynamic (seismic) forces. This means that for the rational design of foundations and earth structures, when determining the strength characteristics of clay soils, it is necessary to take into account its variability under the influence of these factors [1, 2].

Revised Manuscript Received on June 10, 2020.

* Correspondence Author

Khakimov Gayrat Akramovich*, Tashkent Institute of Architecture and civil Engineering. Uzbekistan, Tashkent. E-mail: dilovar.sam@mail.ru

(c) The Authors. Published by Blue Eyes Intelligence Engineering and Sciences Publication (BEIESP). This is an open access article under the CC BY-NC-ND license (http://creativecommons.org/licenses/by-nc-nd/4.0/)

\section{THE ORETICAL AND PRACTICAL PART}

The strength of a rock is judged by its resistance to shear. The strength of clay soils, including their shear resistance, depends on the forces of adhesion and internal friction. According to the proposal of Prof. N. N. Maslov, the resistance of clay soils to shear is expressed by the formula [3] (this applicability for loose soils was established by sh. Coulomb in 1973, which is formulated as follows: the limit resistance of loose soils to shear is directly proportional to the normal stress):

$$
\tau=\operatorname{Ptg} \varphi+C_{w}+C_{C}
$$

Where $\tau$ - is the shear resistance, depending on the normal pressure and density-humidity;

$\mathrm{P}$ - Normal pressure;

$\varphi$ - Internal friction angle, also dependent on density-humidity;

Cw-binding of a rock of water-colloidal nature and reversible character at humidity $\mathrm{W}$;

Cc - rigid structural coupling with the nature of irreversible bonds.

Separating the $\mathrm{Cw}$ and $\mathrm{Cc}$ coupling is difficult and not always possible, so they are combined $(\mathrm{Cw}+\mathrm{Cc}=\mathrm{C})$ and use the above formula in a more General way:

$$
\tau=\operatorname{Ptg} \varphi+\mathrm{C}
$$

The strength characteristics of clay soils (specific adhesion $\mathrm{C}$ and internal friction angle $\varphi$ ) depend mainly on their degree of density and humidity. Experiments have shown that increasing the humidity of clay subsidence soils of the natural state (i.e. from 5 to $7 \%$ ) to full water saturation leads to a decrease in the value of adhesion up to 12-15 times, and the angle of internal friction up to 1.2 times. Strength characteristics of clayey soils in the first place, the clutch increases with increase in the structural strength. The grip and internal friction angle also increase as the soil density increases.

The strength characteristics of clay soils and their changes in static conditions have been studied by many people. Changes in static conditions have been studied by many experts and there is a lot of data on this problem. However, insufficient attention is paid to the issue of changing the strength characteristics of clay soils when exposed to dynamic loads.

Experimental studies of the effect of vibrations on the coefficient of internal friction of soils were first conducted by prof. G. I. Pokrovsky and his colleagues in the laboratory, as well as by D. D. Barkan on a single-plane section device under the action of vertical vibrations.

Published By:

Blue Eyes Intelligence Engineering

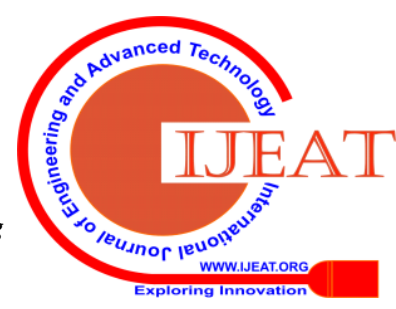


The results of these experiments showed that the coefficient of internal friction depends on the kinetic energy of the vibrations, decreasing with its increase, striving for a certain value that is $25-30 \%$ less than the original value (before vibration) $[1,4]$.

N. A. Preobrazhenskaya and N. A. Savchenko, S. Murayama and T. Shibata tested clays for vibration resistance to shear on two-plane cutoff devices (the first authors tested soil samples with horizontal vibrations, and the other two authors studied them with vertical vibrations).

R. T. Badalyanov and S. R. Mesgyan developed a miniature vibrator, which was used for experimental research on clay soils [1].

According to A. A. Musaelyan, the determining factor in the formation of seismic subsidence is a decrease in the strength characteristics of soils [5].

In laboratory studies A. I. Lahoiski have found that loss of prognosti of soil under dynamic actions is influenced by the following main factors: the amplitude of the oscillations of the mineralogical sastavdalas soil content in the soil particles smaller than $0.001 \mathrm{~mm}$, and soil moisture.

Kh.Z.Rasulov and S.Saifiddinov attach great importance to the connectivity of the soil in terms of strength loss and formation of seismic subsidence of loess soil [6].

Yu. g. Trofimenkov and A. A. Dobrovolsky studied the influence of dynamic effects on the strength characteristics of loess soils and found that only the amount of adhesion decreases under seismic effects (up to $0.01 \mathrm{MPa}$ ) and the angle of internal friction remain unchanged [7].

V. M. Goldstein and A.V. Yermolinsky studying the influence of dynamic influence on the strength characteristics of soils established:

- In clay soils under dynamic load, the internal friction angle changes little (by /-30) however, the grip decreases by 2-3 times;

- increasing the frequency with the same amount of dynamic and static impact reduces the time to failure, without affecting the strength characteristics [8].

\section{SOLUTION}

The results of the experiments showed a significant influence of vibration on the amount of resistance of clay soils to shear. Moreover, the impact of vibration on the shear resistance will be less, the greater the adhesion of the soil. There was also an increase with a decrease in the effect of vibration of the sealing load.

The decrease in soil shear resistance is mainly due to a decrease in the amount of adhesion: that is, the loss of structural strength. This can be proved by the fact of a significant reduction (more than 15 times) in the value of the coupling during vibration. However, the angle of internal friction during vibration changes slightly in the direction of increase, which can be explained by some compaction of the soil during the shift [1].

The above analysis of the state of the issue has shown the importance and at the same times the insufficiency of studying the issues of ensuring the dynamic stability of clay soils.
Also, it should be noted that the above works did not pay due attention to the study of changes in the prognostic characteristics of the development of subsidence deformations of clay soils under various dynamic (seismic) influences, the development of methods for increasing strength characteristics and contributing to the elimination of seismic subsidence deformations of clay soils.In order to thoroughly study the impact of vibration on the strength characteristics of clay soils, we conducted research in the field.For the experimental studies conducted in the field, a vibrator was used (svaw-12 trailer vibratory roller Fig.1,2).

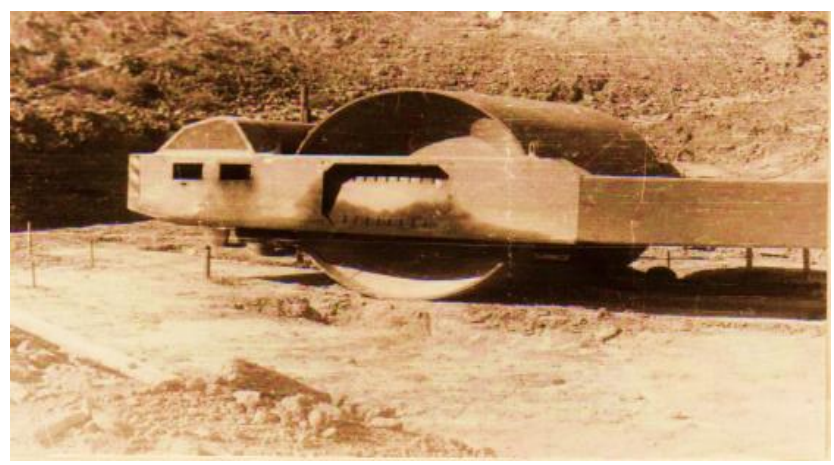

Fig. 1 SVAW - 12 vibration Roller with smooth roller

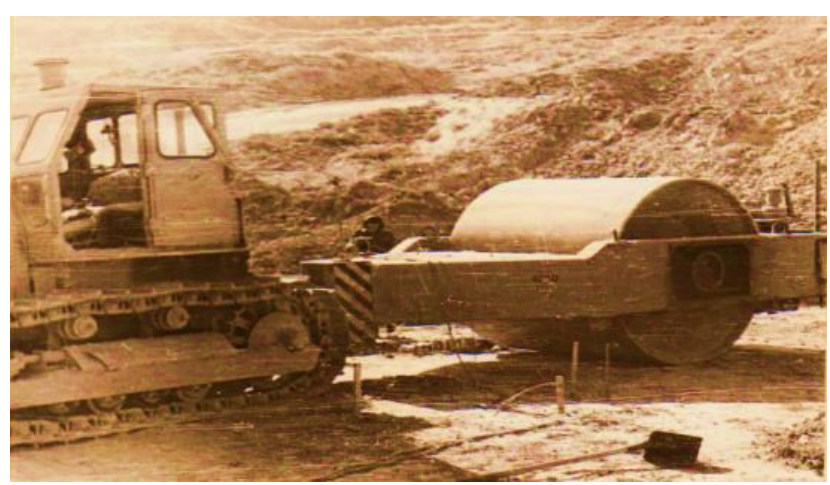

Fig. 2 SVAW - 12 vibrating Rollers with a traction tractor

Trailer vibratory rollers, manufactured in Germany, have three modifications depending on the type of waltz SVAW4, SVAW - 8, SVAW - 12), differing in weight.

The SVAW-12 vibration roller is characterized by the following technical parameters: diameter-2.0 m, width-2.0 $\mathrm{m}$, weight-12 t, operating speed-1.5-5.0 km / h, specific static pressure-59 kg / cm2, exciter force-36 t, vibration frequency up to $25 \mathrm{~Hz}$.

For field research, experimental sites were specially prepared with three experimental sites of the same size 13x6. 5 m (Fig. 3).

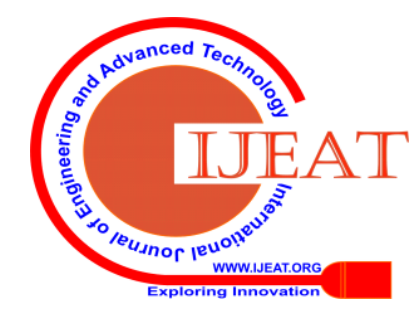



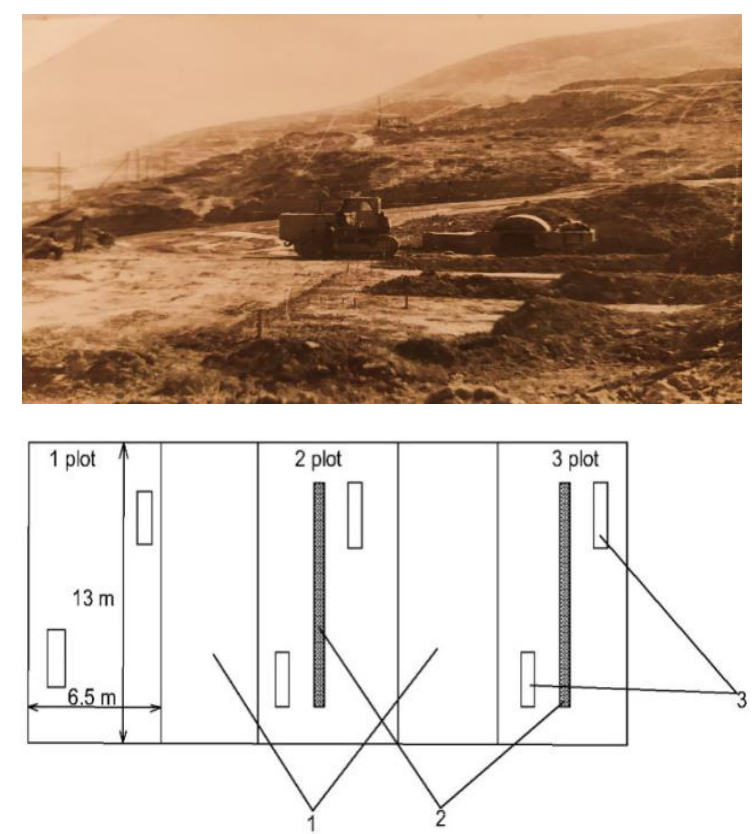

Fig.3 Experimental sections. 1-protective zones, 2trenches, 3-pits

These areas are composed of identical clay soils (loess loams), the physics and mechanical characteristics of which are shown in table 1.

\section{Indicators of physical and mechanical properties of soils}

Table 1

\begin{tabular}{|c|c|c|c|c|c|c|c|c|c|c|c|c|}
\hline \multirow{3}{*}{ Specifications } & \multicolumn{4}{|c|}{ Plot 1} & \multicolumn{4}{|c|}{ Plot 2} & \multicolumn{4}{|c|}{ Plot 3} \\
\hline & \multicolumn{12}{|c|}{ The depth of sampling, m } \\
\hline & 0,1 & 0,5 & 1,5 & 3,0 & 0,1 & 0,5 & 1,5 & 3,0 & 0,1 & 0,5 & 1,5 & 3,0 \\
\hline $\begin{array}{l}\text { Humidity, \% } \\
\text { before the } \\
\text { lock }\end{array}$ & 12 & 15,6 & 14,1 & 13,0 & 11,5 & 15,0 & 14,9 & 11,6 & 12,0 & 15,6 & 16,5 & 12,2 \\
\hline after the lock & \multicolumn{4}{|c|}{ unnoticed } & 15,0 & 17,1 & 19,5 & 20,5 & 14,0 & 15,8 & 17,5 & 18,5 \\
\hline $\begin{array}{lr}\text { Dry } & \text { soil } \\
\text { density, } t / \mathrm{m} 3 \\
\text { before the } \\
\text { lock }\end{array}$ & 1,42 & 1,43 & 1,45 & 1,42 & 1,43 & 1,43 & 1,44 & 1,44 & 1,44 & 1,44 & 1,44 & 1,43 \\
\hline after the lock & & - & - & - & 14,7 & 14,8 & 14,9 & 14,8 & 14,6 & 14,7 & 14,6 & 14,6 \\
\hline $\begin{array}{l}\text { Density of soil } \\
\text { particles, } t / \\
\mathrm{m} 3\end{array}$ & 2,68 & 2,69 & 2,69 & 2,69 & 2,69 & 2,69 & 2,69 & 2,69 & 2,69 & 2,69 & 2,69 & 2,69 \\
\hline $\begin{array}{l}\text { The number } \\
\text { of plasticity }\end{array}$ & 9 & 10,2 & 10 & 10,1 & 9,3 & 10,2 & 10,3 & 10,6 & 9 & 10 & 10,1 & 10,6 \\
\hline $\begin{array}{l}\text { Adhesion } \\
\text { strength, } \\
\text { MPA }\end{array}$ & - & 0,070 & 0,064 & 0,059 & - & 0,064 & 0,055 & 0,045 & - & 0,059 & 0,086 & 0,047 \\
\hline $\begin{array}{l}\text { Angle of } \\
\text { internal } \\
\text { friction, deg }\end{array}$ & & $28^{\circ}$ & $29^{\circ}$ & $28^{a}$ & & $29^{\circ}$ & $28^{\circ}$ & $28^{\circ}$ & - & $28^{\circ}$ & $28^{\circ}$ & 270 \\
\hline Name & & Light & tloam & & & Ligh & lloam & & & Light & toam. & \\
\hline
\end{tabular}

In order to create different humidity in identical ground conditions, the thickness was soaked. To soak the soil in the middle of the second and third sections, trenches of $8 \times 0$, $4 \times 1,4$ and $8 \times 0,4 \times 1,0 \mathrm{~m}$ were dug. The Trenches were filled with small rubble of $5-20 \mathrm{~mm}$ in size. Then, continuous locking of the sections was carried out using a water hose for 12-15 days. The required volume of water to obtain the specified thickness humidity was determined by calculation. After stopping the lock, soil samples were taken for 30 days to determine their physical and mechanical parameters (table.1) As a result of these works, we had three identical sites that differ only in humidity.

The soil humidity in the areas corresponded to:

Plot \#1 13-14\%, plot \#2 19-20, plot \#3 16-17 in order to isolate the humidity of each plot during their locking; a $6 \mathrm{~m}$ wide sewn zone was left between them.

Then we started the second stage of the experiment related to the study of soil vibrato-compaction. Vibration compaction was performed on each section in several places at intervals of $1.5-2 \mathrm{~m}$. The vibrating roller moves along each section in a straight line. At the same time, you can create different vibrations and duration of soil vibrations by adjusting the operating mode of the roller.

After the implementation of re-vibration were selected soil samples to determine the performance aristomenes properties (table.2)

Table 2.

\begin{tabular}{|c|c|c|c|c|c|c|c|c|c|c|c|c|}
\hline \multirow{2}{*}{$\begin{array}{l}\text { The } \\
\text { depth } \\
\text { of the } \\
\text { layer, } \\
\text { m }\end{array}$} & \multicolumn{3}{|c|}{$\begin{array}{l}f=12.5 \Gamma \mathrm{Tw} / \mathrm{mu} / \\
\mathrm{t}=30 \mathrm{c}\end{array}$} & \multicolumn{3}{|c|}{$\begin{array}{l}f=23.5 \Gamma \mathrm{n} / \mathrm{mun} / \\
\mathrm{t}=30 \mathrm{c}\end{array}$} & \multicolumn{3}{|c|}{$\begin{array}{l}f=12.5 T \text { T/ } \\
t=90 \mathrm{c}\end{array}$} & \multicolumn{3}{|c|}{$\begin{array}{l}f=23.5 \Gamma \text { T } / \text { mur } \\
t=90 \mathrm{c}\end{array}$} \\
\hline & W\% & $\begin{array}{l}P d \\
\mathrm{~T} / \mathrm{Mr}^{\mathrm{S}}\end{array}$ & $\begin{array}{l}P d \\
\mathrm{~T} / \mathrm{M}^{\mathrm{j}}\end{array}$ & W\% & $\begin{array}{l}P d \\
\mathrm{~T} / \mathrm{y}^{3}\end{array}$ & $\begin{array}{l}P d \\
\mathrm{~T} / \mathrm{s}^{3}\end{array}$ & W\% & $\begin{array}{l}P d \\
T / \mathbb{I}^{3}\end{array}$ & $\begin{array}{l}P^{\prime} d \\
\mathrm{~T} / \mathrm{M}^{3}\end{array}$ & W\% & $\begin{array}{l}P d \\
\mathrm{~T} / \mathrm{MI}^{3}\end{array}$ & $\begin{array}{l}P_{d} d \\
\mathrm{~T} / \mathrm{vr}^{3}\end{array}$ \\
\hline & & & & 12 & & & 29 & 70 & & 10.5 & & \\
\hline & & & & & & & 1. & & & 0.6 & & \\
\hline & 15.7 & 1. & 1. & 16.6 & 1.68 & 1 & 14 & .70 & .46 & 11.5 & 1.68 & \\
\hline \multirow{3}{*}{0} & & & & 15 & & 43 & 15.5 & 65 & & 14.0 & & \\
\hline & & & & 16.0 & 1.59 & 1 & 18.8 & 1.62 & & 15.0 & 1.60 & \\
\hline & 0.0 & & 1. & 18.6 & 1.58 & 1.47 & 18.8 & 1.61 & 1.47 & 15.0 & 1.63 & \\
\hline & & & & 16.0 & 1.51 & 1.45 & 16 & 1.52 & 45 & 14.0 & 1.50 & \\
\hline & & & 1. & 19. & 1. & & 19 & 1.51 & & 16.7 & 1.51 & \\
\hline & 20.5 & 1.48 & 1.46 & 21.5 & 1.50 & 1.46 & 20 & 1.50 & 1.50 & 17.7 & 1.52 & \\
\hline
\end{tabular}

Note: P/d - density of dry soil before vibration;

Pd-dry soil stability after vibration;

$\mathrm{t}$ - The duration of the vibration;

$\mathrm{f}$ - Frequency of vibration.

More than 30 different studies with soil vibration were carried out on the experimental sites. Processing of research results allowed us to establish the following dependencies. Let's look at the data in the table.2. Where the results of experiments on changes in soil moisture density during vibration with different duration and minimum positions are summarized.

The dynamic mode of the vibrating roller could be adjusted according to the speed of movement and the mode of its operation (different frequencies).

Changes in soil density as a result of violation of their structure and deformation will decrease in depth of the thickness, which is quite natural. However, on the surface horizons of the thickness, where intense fluctuations are transmitted, there is a sharp change in the density of the soil. More severe deformation of the soil occurs when the vibrating roller is operating at maximum mode.

Many experiments conducted in the field with thickness vibration have shown an increase in soil deformation with an increase in the duration of vibration, which in quantitative terms falls with the depth of the thickness.

There is a linear relationship between the increase in the density of the soil and the duration of the oscillation, which, according to the number of expressions, falls with the depth of the thickness.

In experimental studies conducted in the field, we paid special attention to the further behavior of soils after vibration. Observations and measurements of soil indicators were made for 2 months. The results of the observation are summarized in table 3.

Published By:

Blue Eyes Intelligence Engineering

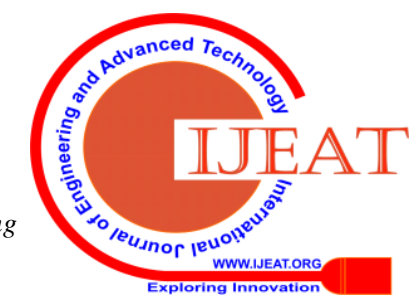


The change in strength characteristics of soils after the implementation of vibration

Table 3

\begin{tabular}{|c|c|c|c|c|c|c|c|c|}
\hline \multirow{3}{*}{ Time } & \multicolumn{8}{|c|}{ Depth of sampling $\mathrm{H}=0.4-0.5 \mathrm{M}$} \\
\hline & \multicolumn{4}{|c|}{$\begin{array}{l}\text { Vibration frequency } f=12.5-14 \Gamma \mathrm{I} \\
\text { Vibration duration } t=30 \text { seconds }\end{array}$} & \multicolumn{4}{|c|}{$\begin{array}{l}\text { Vibration frequency } f=12.5-14 \Gamma \text { ц } \\
\text { Vibration duration } t=90^{\circ} \mathrm{c}\end{array}$} \\
\hline & $\begin{array}{l}\mathrm{W} \\
\%\end{array}$ & $\begin{array}{c}P d \\
\mathrm{~T} / \mathrm{M}^{3}\end{array}$ & $\begin{array}{c}\varphi \\
\text { град }\end{array}$ & $\begin{array}{c}\mathrm{C} \\
\mathrm{M \Pi а}\end{array}$ & $\begin{array}{l}\mathrm{W} \\
\%\end{array}$ & $\begin{array}{c}P d \\
\mathrm{~T} / \mathrm{M}^{3}\end{array}$ & $\begin{array}{c}\varphi \\
\text { град }\end{array}$ & $\begin{array}{c}\mathrm{C} \\
\mathrm{M} \Pi \mathrm{a}\end{array}$ \\
\hline Before vibration & 17.6 & 1.48 & $25^{0}$ & 0.046 & 16.1 & 1.43 & $25^{0}$ & 0.049 \\
\hline $\begin{array}{l}\text { 1-3 days after } \\
\text { vibration }\end{array}$ & 18.0 & 1.60 & $26^{0} 30$ & 0.030 & 17.5 & 1.66 & $29^{0}$ & 0.035 \\
\hline $\begin{array}{l}50 \text { days } \\
\text { sibratiog }\end{array}$ & 16.6 & 1.62 & $27^{0}$ & 0.059 & 15.1 & 1.67 & $30^{\circ}$ & 0.060 \\
\hline Before vibration & 16.3 & 1.45 & $24^{0} 30$ & 0.049 & 16.3 & 1.45 & $24^{0} 30$ & 0.049 \\
\hline $\begin{array}{l}\text { 1-3 days after } \\
\text { vibration }\end{array}$ & 19.1 & 1.61 & $27^{0} 30$ & 0.025 & 20.3 & 1.62 & $27^{0}$ & 0.020 \\
\hline $\begin{array}{l}\mathbf{5 0} \text { days after } \\
\text { vibration }\end{array}$ & 16.6 & 1.63 & $28^{0}$ & 0.067 & 17.5 & 1.63 & $28^{0} 30$ & 0.059 \\
\hline
\end{tabular}

\begin{tabular}{|c|c|c|c|c|c|c|c|c|}
\hline \multirow{3}{*}{ Time } & \multicolumn{8}{|c|}{ Depth of sampling $\mathrm{H}=0.4-0.5_{\mathrm{M}}$} \\
\hline & \multicolumn{4}{|c|}{$\begin{array}{l}\text { Vibration frequency } f=21.5-23.5 \Gamma \text { प } \\
\text { Vibration duration } t=30 \mathrm{c}\end{array}$} & \multicolumn{4}{|c|}{$\begin{array}{l}\text { Vibration frequency } f=21.5-23.5 \Gamma \mathrm{n} \\
\text { Vibration duration } t=90^{\circ} \mathrm{c}\end{array}$} \\
\hline & $\begin{array}{l}\mathrm{W} \\
\%\end{array}$ & $\begin{array}{c}P d \\
\mathrm{~T} / \mathrm{M}^{3}\end{array}$ & $\begin{array}{c}\varphi \\
\text { град }\end{array}$ & $\begin{array}{c}\mathrm{C} \\
\mathrm{M \Pi а}\end{array}$ & $\begin{array}{l}\mathrm{W} \\
\%\end{array}$ & $\begin{array}{l}P d \\
\mathbf{T} / \\
\mathbf{M}^{3}\end{array}$ & $\begin{array}{c}\varphi \\
\text { град }\end{array}$ & $\begin{array}{c}\text { C } \\
\text { МПа }\end{array}$ \\
\hline Before vibration & 17.6 & 1.48 & $25^{0}$ & 0.046 & 16.1 & 1.43 & $25^{0}$ & 0.049 \\
\hline $\begin{array}{l}\text { 1-3 days after } \\
\text { vibration }\end{array}$ & 17.7 & 1.60 & $27^{0} 30$ & 0.040 & 16.1 & 1.65 & $29^{0}$ & 0.045 \\
\hline $\begin{array}{l}50 \text { days after } \\
\text { vibration }\end{array}$ & 16.5 & 1.62 & $28^{0} 30$ & 0.068 & 14.3 & 1.65 & $30^{0} 30$ & 0.079 \\
\hline Before vibration & 16.3 & 1.45 & $24^{0} 30$ & 0.049 & 16.3 & 1.45 & $24^{0} 30$ & 0.049 \\
\hline $\begin{array}{l}\text { 1-3 daxs after } \\
\text { vibration }\end{array}$ & 19.1 & 1.56 & $27^{0} 30$ & 0.025 & 16.5 & 1.61 & $27^{0} 30$ & 0.040 \\
\hline $\begin{array}{l}50 \text { days after } \\
\text { vibration }\end{array}$ & 15.7 & 1.58 & $28^{0} 30$ & 0.080 & 12.5 & 1.62 & $29^{0}$ & 0.095 \\
\hline
\end{tabular}

A more intensive increase in the density of pre-vibrated soils with a high frequency, which is an important indicator for the purpose of soil compaction measures.

Increasing the soil density over time is accompanied by an increase in its strength indicators (taking into account internal friction and adhesion). Moreover, this increase in its strength indicators took into account internal friction, depending on the duration of vibration. (Fig. 4,5)

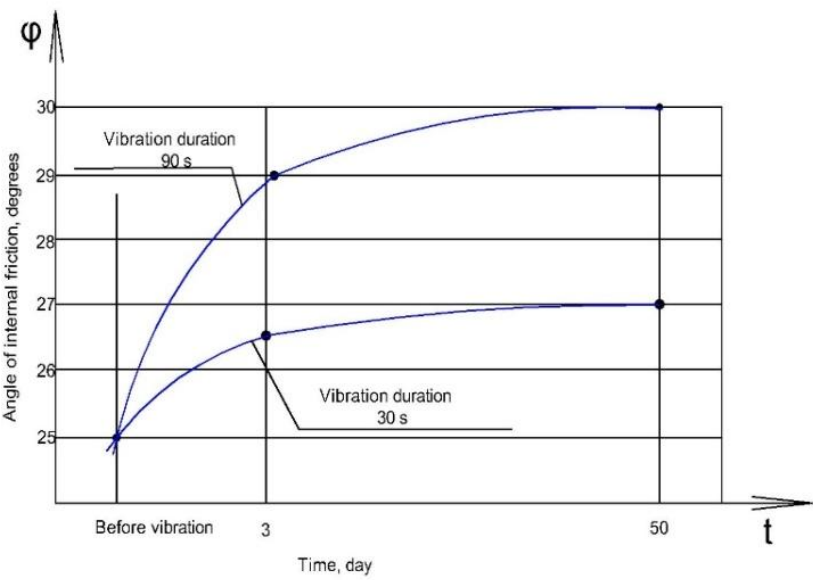

Fig.4. the character of increasing the angle and internal friction of loess loam over time. Vibration frequency

$$
f=12.5 \Gamma u
$$

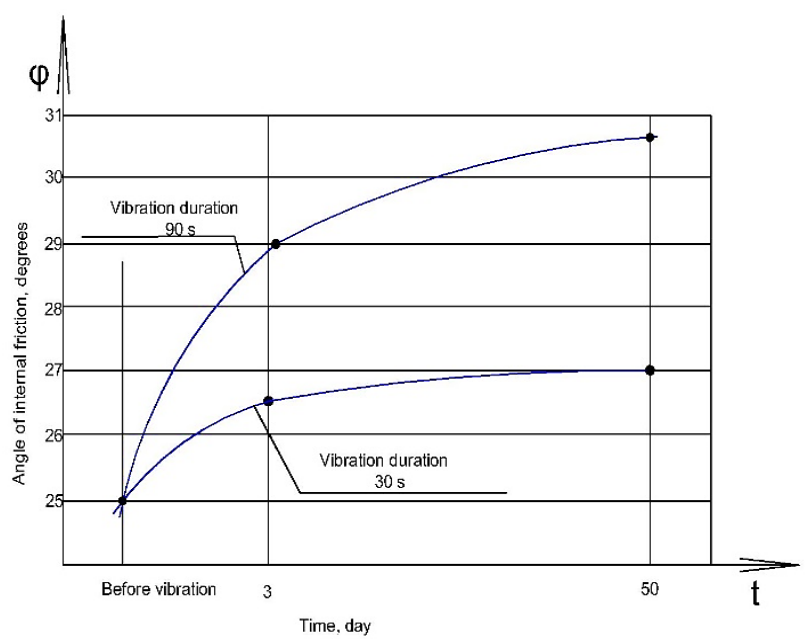

Fig.5. the nature of the increase in the angle, internal friction of the vibrated loess loam over time. Vibration

$$
\text { frequency } f=23.5 \Gamma u
$$

So, when the vibration lasts 30 seconds. The increase in the internal friction factor for 50 days is 30, and at 902 seconds. This value is 50 .

Similar, but more prominent this circumstance is characteristic for the bonding of the soil (Rus 6). Vibration, as well as other dynamic effects on the soil causes a sharp decrease in adhesion. As a result, in water-saturated soils, there is a drop in strength, in some cases, their transition to a liquefied state. This phenomenon also occurred in our experiments, when the vibration roller worked at the maximum mode (frequency $\mathrm{f}=25 \mathrm{~Hz}$.) in 2 areas with the highest humidity $(\mathrm{W}>200)$.

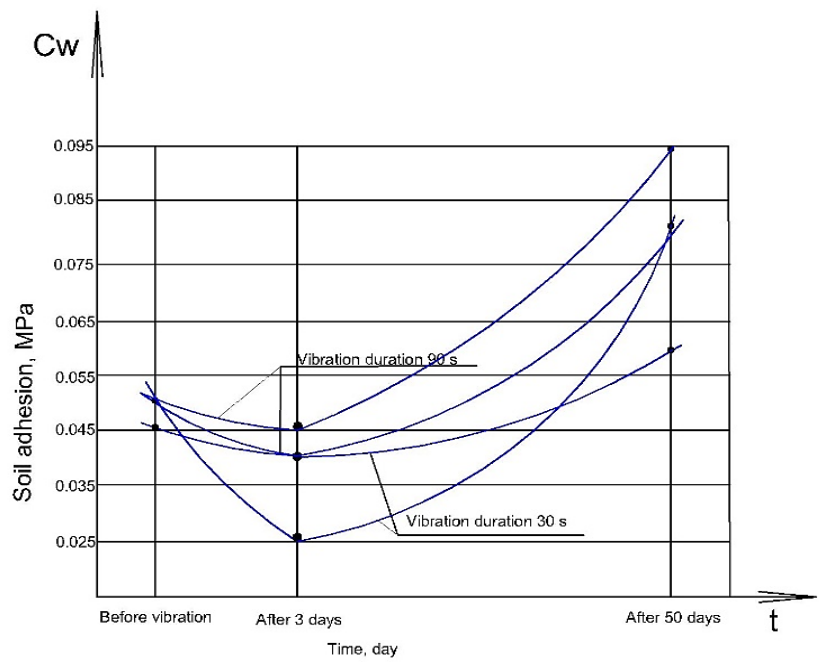

Fig. 6. The nature of the change in soil adhesion over time. Vibration frequency $f=12.5 \Gamma u$

Over time, there is an increase in soil adhesion, obviously as a result of the soil gaining new strength and compaction under the influence of its own weight. Within 50 days, the coupling value from $0.045 \mathrm{MPa}$ rose to $0.085 \mathrm{MPa}$ (Fig. 7).

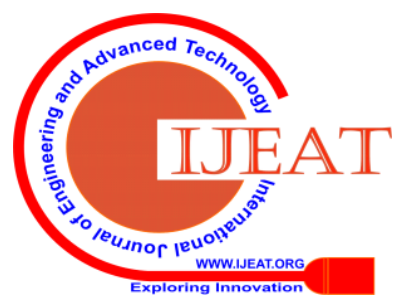




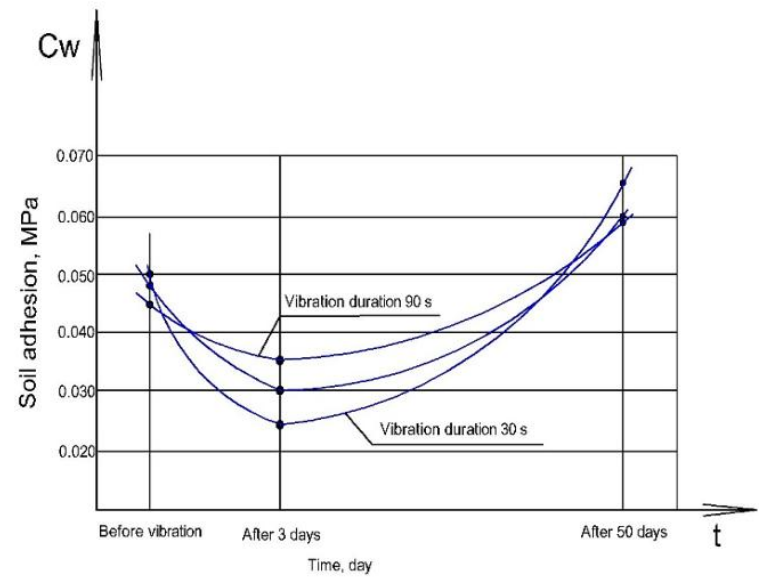

Fig.7. The nature of the change in soil adhesion over time. Vibration frequency $f=23.5 \Gamma u$

\section{CONCLUSIONS}

As follows from the above analysis of the results of the experiment, the vibration process has a significant impact on changing the strength characteristics of soils. This influence especially affects the strength of the soil adhesion. In the process of vibration, there is a sharp decrease in the coupling force, which is apparently due to a violation of the structure of the soil and its compaction. And then at the end of the compaction process, a gradual increase in the value of connectivity to $1.5-2.0$ times occur. This circumstance is also related to the humidity state of the soil. As shown by our research, the greatest effect of vibration compaction is achieved when the soil moisture corresponding to the optimal value.

Field studies have also shown an intensive increase in the density of pre-vibrated soils over time. A particularly large effect is achieved in such conditions when high-frequency vibrations are applied to the ground.

\section{REFERENCES}

1. Meschyan S. R. Initial and long-term strength of clay soils. Moscow: "Nedra" 1978. - 208 p.

2. RasulovKh. Z., Khakimov G. A. influence of vibration on changing the strength characteristics of soils Collection of scientific works of Toshpn "computers incalculations and practice of designing construction objects". - Tashkent: Caspn, 1986, with 76-82.

3. Maslov N.N. Fundamentals of engineering Geology and soil mechanics. - Moscow: "Higher school, 1982. - 512 PP.

4. Barkon, D.D. Vibrometer In construction. - M.:Gosstroiizdat, 1959. 315c.

5. Musaelyan A. A. Some results of studies of subsidence soils under cyclic loads. Reports By A. N. Taj. - Dushanbe: 1965, vol. 8, no. 11, pp. 44-47.

6. Rasulov H. Z. Seismic Stability of soil bases-Toshkent: Uzbekistan, 1984. - $192 \mathrm{p}$.

7. Trofimenkov Yu. G., Dobrovolsky A. A. Influence of simulated seismic effects on strength and deformation properties of soils - in kN. Waves in soils and issues of vibrometry. - Tashkent: Fan, 1975, pp. 118-126.

8. Goldstein V. M., ermolinsky A.V. Study of changes in soil strength characteristics under dynamic load. -Materials of the 5th all-Union conference on the dynamics of foundations and underground structures. Vol. 1-M.: 1981, p. 224-226.

\section{AUTHORS PROFILE}

Khakimov Gayrat Akramovich. Tashkent Institute of Architecture and civil Engineering. Candidate of geological and mineralogical Sciences, associate Professor of the Department of buildings and structures. Studies of the prognostic structure of moist loessial soils with seismic vasdeciosis have been conducted 5 manuals author of more than 100 scientific articles.

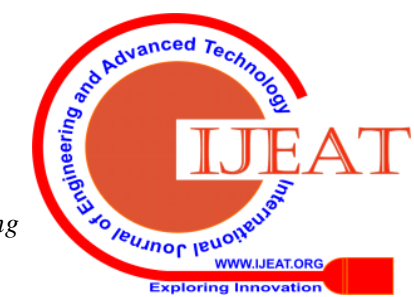

